\title{
SCREENING OF BIOACTIVE COMPOUNDS SYNTHESIZED BY MICROALGAE: A PROGRESS OVERVIEW ON EXTRACTION AND CHEMICAL ANALYSIS
}

\author{
D. PATRAS ${ }^{a, b}$, C.V. MORARU ${ }^{b}$, C. SOCACIU ${ }^{a, b^{*}}$
}

\begin{abstract}
Considering the high biodiversity of microalgae and their important impact on economy and ecological balance, new screening techniques are needed for their phenotypic characterization and efficient valorization of bioactive components. This represents one the key purpose of the emerging bioeconomy concept, involving new biorefinery technologies coupled with advanced analytical tools. The article presents an overview of the recent extraction and chemical techniques used to recover, separate and characterize the main bioactive molecules (lipids and fatty acids, carbohydrates, proteins and mycosporine-like amino acids chlorophylls and carotenoid pigments) syntesized by microalgae, considering their interesting applications in food, pharmaceutical and cosmetic industries. Special focuses will be directed towards the cell disintegration and extraction procedures, identification and quantification of main metabolites by advanced analytical techniques.
\end{abstract}

Keywords: microalgae, bioactive compounds, cell disruption, extraction, spectrometry, chromatography

\section{INTRODUCTION}

The green microalgae and cyanobacteria (blue-green microalgae), typically found in freshwater and marine systems are an important group of unicellular $(3-10 \mu \mathrm{m})$, photosynthetic microorganisms with great economic and ecologic impact. They are dwelling in different

${ }^{a}$ Faculty of Food Science and Technology, University of Agricultural Sciences and Veterinary Medicine Cluj-Napoca, 3-5, str. Manastur, 400372 Cluj-Napoca, Romania

${ }^{b} R \& D$ Center for Applied Biotechnology, Proplanta SRL Cluj-Napoca, Romania, $12 \mathrm{G}$ str. Trifoiului, 400478 Cluj-Napoca, Romania

Corresponding author: carmen.socaciu@usamvcluj.ro 
environments such as freshwater, marine water or surface of moist rocks, growing rapidly, living in harsh conditions and withstanding environmental stressors, such as heat, cold, anaerobiosis, salinity, photooxidation, osmotic pressure and exposure to ultra-violet radiation. Being capable of converting solar energy to chemical substances via photosynthesis, such organisms are able to synthesize interesring, unique bioactive molecules with multiple applications. The large biodiversity of microalgae includes approximately $200,000-800,000$ species in many different genera, of which about 50,000 species are described and around 15,000 novel compounds originating from algal biomass have been identfied. The most studied microalgae until now, Haematococcus pluvialis, Spirulina, Chlorella vulgaris, Nannochloropsis oculata, Arthrospira platensis, are an important source of aminoacids-peptides-proteins, vitamins, minerals, polyunsaturated fatty acids, secondary metabolites (sterols, pigments) and minerals [1]. A large variety of functional ingredients isolated from such species can be extracted and used to produce food or cosmetic supplements or functional foods with multiple health benefits $[2,3]$.

This overview presents an updated screening of the literature regarding the extraction and chemical analysis of bioactive compounds found in microalgae, aiming the present and future possible applications in food, pharmacy and cosmetics areas.

The overview include a first part dedicated to the extraction of active microalgae ingredients, followed by new data on the main metabolites of scientific and applicative interests, their identification and quantification by advanced analytical techniques.

\section{BIOACTIVE METABOLITES FOUND IN MICROALGAE SPECIES}

The microalgal metabolism is very versatile, reacting fast to changes in the external environment and this aspect is valorized technologically, since the environmental stress induces modifications of the biosynthetic pathways. Both primary and secondary metabolites from microalgae are considered promising natural sources of bioactive compounds since approx. $40 \%$ of global photosynthesis being due to these microorganisms [4]. Figure 1 presents a simplified scheme of the primary and secondary metabolism of microalgae. 


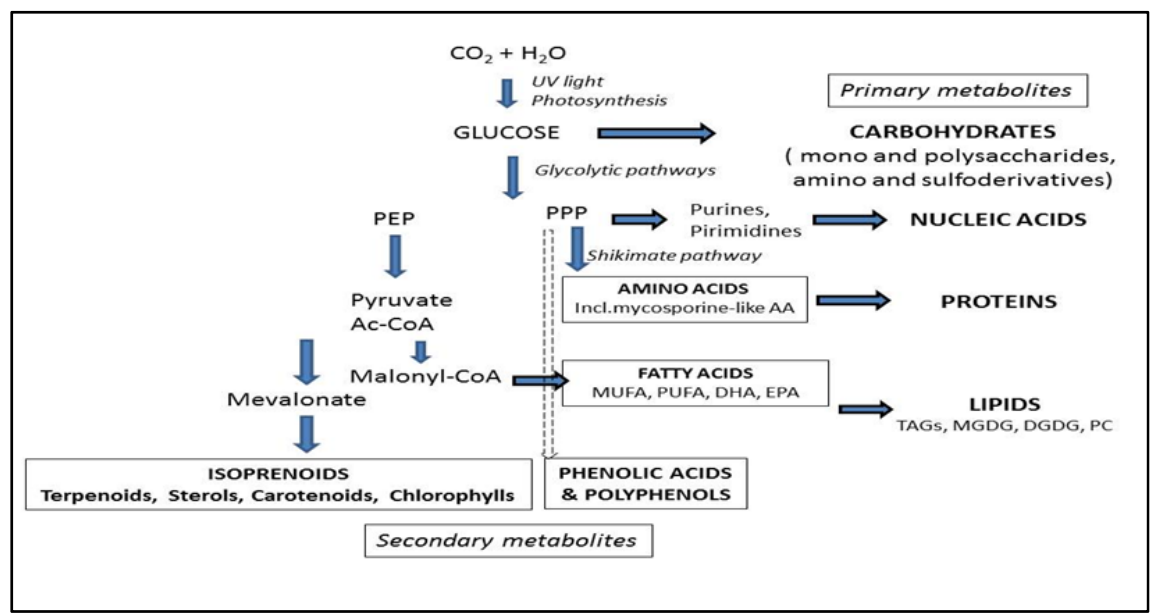

Figure 1. Main biosynthetic pathways which are producing primary and secondary metabolites in microalgae.

Table 1. Carbohydrates and proteins extracted and analysed from different species of microalgae. Relevant references are added.

\begin{tabular}{|c|c|c|}
\hline Species & Extraction protocols/analysis & $\begin{array}{l}\text { Compounds } \\
\text { identified, ref. }\end{array}$ \\
\hline Nannochloropsis sp. & $\begin{array}{l}\text { Freeze-dried algal mass extracted in methanol } \\
\text { followed by saponification. }\end{array}$ & Proteins $[8,9]$ \\
\hline Chlorella pyrenoidosa & $\begin{array}{l}\text { Cell lysed biomass mixed with ammonium sulphate, } \\
\text { followed by delipidation with t-butanol. Proteins } \\
\text { precipitated and after acidic hydrolysis, the amino } \\
\text { acid analysis was done by HPLC }\end{array}$ & $\begin{array}{l}\text { Proteins } \\
\text { Amino acids } \\
\text { Starch, Cellulose } \\
{[7]}\end{array}$ \\
\hline $\begin{array}{l}\text { Haematococcus pluvialis } \\
\text { Nannochloropsis ocul. } \\
\text { (see water algae) } \\
\text { Arthrospira platensis and } \\
\text { Chlorella vulgaris (sweet } \\
\text { water algae) }\end{array}$ & $\begin{array}{l}\text { Pre-treatment by freeze-drying, High-pressure cell } \\
\text { disruption, ultrasonication } \\
\text { Manual grinding and chemical treatment in basic } \\
\text { and acid sol. }\end{array}$ & $\begin{array}{l}\text { Water-soluble } \\
\text { proteins [10] }\end{array}$ \\
\hline BTM 11 & $\begin{array}{l}\text { Dried biomass on liquid nitrogen, sonication and } \\
\text { centrifugation. Supernatant precipitated with } \\
\text { ammoniumn sulfate and purified by Sephadex G-50 } \\
\text { gel filtration. } \\
\text { Separation of proteins by SDS-PAGE electrophoresis. }\end{array}$ & Lectins [11] \\
\hline $\begin{array}{l}47 \text { microalgae strains } \\
\text { (incl. green /red algae, } \\
\text { and diatoms) }\end{array}$ & $\begin{array}{l}\text { The algal biomass was hydrolyzed in acid media } \\
\text { and analysed by ninhydrin method with absorption } \\
\text { of amino acids at } 575 \mathrm{~nm} \text {. }\end{array}$ & Total proteins [12] \\
\hline $\begin{array}{l}\text { Chlorella pyrenoidosa } \\
\text { (sweet water microalgae) }\end{array}$ & $\begin{array}{l}\text { Cell lysed biomass mixed with ammonium sulphate, } \\
\text { delipidation with } t \text {-butanol. Proteins precipitated by acidic } \\
\text { hydrolysis, carbohydrates determined by spectrometry }\end{array}$ & $\begin{array}{l}\text { Total carbohydrates } \\
\text { Starch Cellulose } \\
{[11]}\end{array}$ \\
\hline $\begin{array}{l}\text { Forty-seven microalgae } \\
\text { strains, including green algae, } \\
\text { red algae, and diatoms }\end{array}$ & $\begin{array}{l}\text { Defatted biomass was hydrolyzed in acidic media. } \\
\text { Glucans were determined by the modified thymol- } \\
\text { sulfuric acid method }\end{array}$ & $\beta$ - $\alpha$ - glucans [12] \\
\hline
\end{tabular}


The secondary metabolism shows a limited distribution, while the primary metabolism furnishes intermediates for the synthesis of essential macromolecules [5]. The microalgal carbohydrates are complex and include mixtures of neutral sugars, amino sugars and uronic- or sulfo-acids, depending on the species and environmental factors [6], as presented in Table 1. Microalgae are considered an alternative high-value protein source since they contain all essential amino acids [7] (Table 1). There are many methods for proteins extraction from microalgae: ultrafiltration, precipitation, chromatography, dialysis and centrifugation. Precipitation seems to be scalable for industrial processes but it has also its limitation. Precipitation by salting out has low recovery, while precipitation by isoelectric focusing and solvent can cause irreversible denaturation of proteins.

Mycrosporine-like amino acids (MAAs), a specific class of metabolites have important roles in the protection of aquatic organisms against solar radiation. This can be a reason for using MAAs extracts as ingredients for skin protection in suncare products [5]. Microsporine-like aminoacids (MAAs) were extracted and analysed from different species of microalgae, as presented in Table 2 .

Table 2. Microsporine-like aminoacids (MAAs) extracted and analysed from different species of microalgae. Relevant references are added.

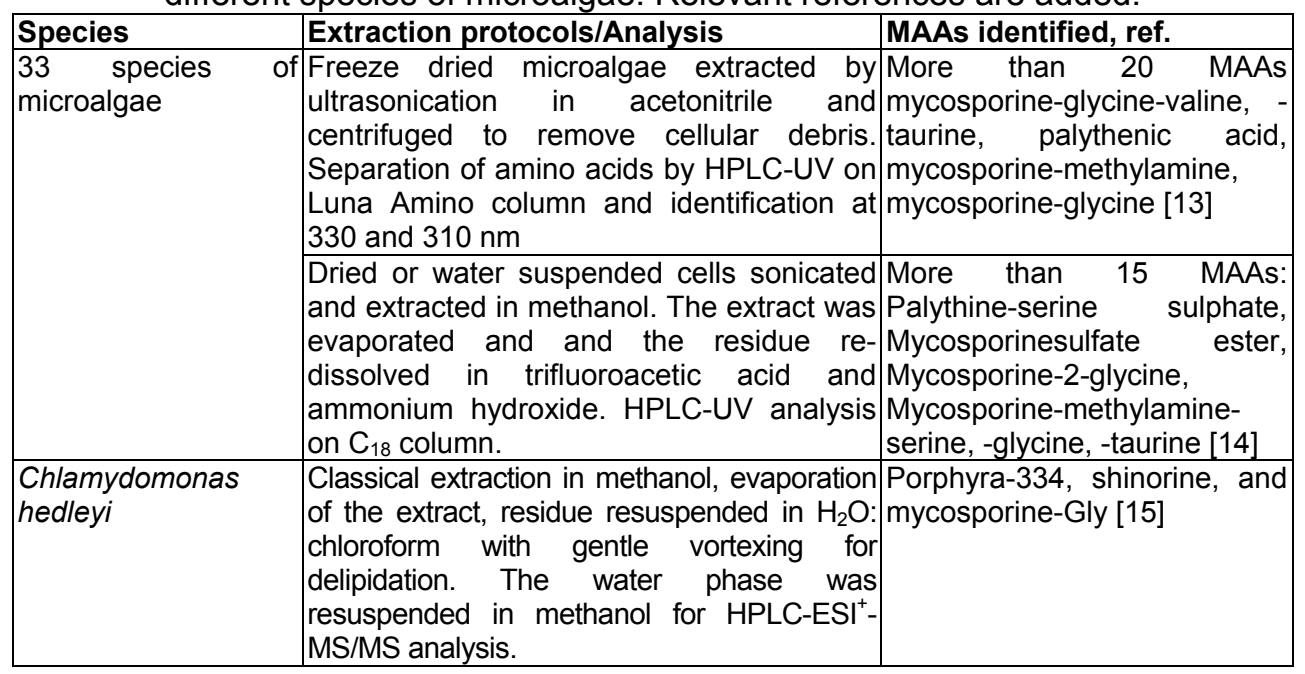

The protocols used to extract mycosporine-like aminoacids varies among studies, every species having a different protocol, using ethanol or methanol, with or without cell wall disruption by sonication or in the presence of chemicals, at different temperatures and for different duration [16]. 
Table 3. Lipids, fatty acids and pigments extracted and analysed from different species of microalgae. Relevant references are added.

\begin{tabular}{|c|c|c|}
\hline Microalgae & $\begin{array}{l}\text { Cell wall disruption/Extraction } \\
\text { protocols/analysis }\end{array}$ & $\begin{array}{l}\text { Active compounds } \\
\text { extracted, ref. }\end{array}$ \\
\hline $\begin{array}{l}\text { Nannochioropsis } \\
\text { gaditana }\end{array}$ & $\begin{array}{l}\text { Mechanical/vortex ultrasounds assisted } \\
\text { disruption/centrifugation, freezing/unfreezing. Use } \\
\text { of methanol, acetone, ethanol. }\end{array}$ & Pigments [17] \\
\hline Scenedesmus obliquus * & $\begin{array}{l}\text { Freeze-drying, quartz grinding, ultrasounds. } \\
\text { Extraction at low temperature and successive } \\
\text { extraction with acetone. }\end{array}$ & $\begin{array}{l}\text { Pigments and fatty } \\
\text { acids [18] }\end{array}$ \\
\hline $\begin{array}{l}\text { Chiorella* } \\
\text { Chroococcus* }\end{array}$ & $\begin{array}{l}\text { Osmosis, grinding with glass powder. } \\
\text { Lyophilisation. Extraction with cold/preheated/ } \\
\text { boiling acetone. }\end{array}$ & Pigments [4] \\
\hline $\begin{array}{l}\text { Chlamydomonas } \\
\text { variabills, } \\
\text { Chlorella vuigaris* } \\
\text { Haematococcus pluvialis, } \\
\text { Scenedesmus* } \\
\text { Chroococcus turgidus, etc. }\end{array}$ & $\begin{array}{l}\text { Liophilisation of algae followed by classical } \\
\text { extraction using chloroform and methanol. } \\
\text { Alternative extraction of algae powder or paste, } \\
\text { mixed with } n \text {-hexane and isopropanol, centrifuged } \\
\text { at } 800 \mathrm{rpm} \text { at ambient conditions for } 7.5 \mathrm{~h} \text {, and } \\
\text { filtred. }\end{array}$ & Total lipids [19], [20] \\
\hline Chlorococcum sp* & $\begin{array}{l}\text { Supercritical } \mathrm{CO}_{2} \text { extraction at pressures } 10 \text { to } 50 \\
\text { MPa and } 60 \text { or } 80^{\circ} \mathrm{C} \text {. Extraction time: } 80-120 \mathrm{~min} \text {. } \\
\text { Dynamic Soxhlet extraction in } n \text {-hexane, } 7.5 \mathrm{~h}\end{array}$ & PUFAs [20] \\
\hline Pavlova viridis & $\begin{array}{l}\text { Classical Chloroform/methanol extraction ( } \\
\text { method Bligh 1959), chloroform extract analysed } \\
\text { GC-MS. }\end{array}$ & $\begin{array}{l}\text { MUFAS, EPA, DHA } \\
{[20]}\end{array}$ \\
\hline \multirow[t]{2}{*}{ Nannochloropsis sp. } & $\begin{array}{l}\text { Lipid transmethylation of freeze-dried samples } \\
\text { treated with methanol/acetyl chloride. The final } \\
\text { hexane extract was analysed }\end{array}$ & EPA [8], [9] \\
\hline & \begin{tabular}{|l|} 
Fatty acid methyl esters (FAMEs) were prepared \\
by trans-methylation with methanol-acetyl chloride
\end{tabular} & $\begin{array}{l}\text { Fatty acids (C14:0, } \\
\text { C16:0, C22:5 n-6, } \\
\text { DHADDA, C22:6 } \\
n-3), \text { Squalene [21] }\end{array}$ \\
\hline Tetraselmis chuil & $\begin{array}{l}\text { Fatty acid methyl esters (FAMEs) were prepared } \\
\text { by trans-methylation with methanol-acetyl chloride }\end{array}$ & $\begin{array}{l}\text { Fatty acids C16:0, } \\
\text { DHA, methylated } \\
\text { C16:1,1,2- benzene- } \\
\text { dicarboxylic acid [22] }\end{array}$ \\
\hline Paviova lutheri & $\begin{array}{l}\text { Direct transesterification with acetyl chloride. The } \\
\text { Fatty Acid Methyl Esters (FAMEs) were analysed } \\
\text { by GC-MS. }\end{array}$ & $\begin{array}{l}\text { Fatty acids C16:0, } \\
\text { C16:1, C18:2, C18:4, } \\
\text { EPA, DHA [23] }\end{array}$ \\
\hline Chlorella kessleri* & $\begin{array}{l}\text { Chloroform/methanol extraction, and subsequent } \\
\text { fractionation by two-dimensional TLC on } \\
\text { precoated silica }\end{array}$ & $\begin{array}{l}\text { MGDG, DGDG, PC, } \\
\text { PE [24] }\end{array}$ \\
\hline $\begin{array}{l}\text { Nannochloropsis salina } \\
\text { Chlorella vulgaris * } \\
\text { Arthrospira platensis } \\
\text { Scenedesmus obliquus * }\end{array}$ & $\begin{array}{l}\text { Extraction in different solvent mixtures. } \\
\text { Chloroform-methanol(1:1) gave the highest lipid } \\
\text { content. }\end{array}$ & $\begin{array}{l}\text { Total and non-polar } \\
\text { lipids [25] }\end{array}$ \\
\hline \multirow{2}{*}{$\begin{array}{l}\text { Dunaliella tertiolecta and } \\
\text { Tetraselmis suecica }\end{array}$} & Extraction in different solvent mixtures. & Vitamin E [26] \\
\hline & $\begin{array}{l}\text { Extraction in different solvent mixtures. 2- } \\
\text { propanol substituted methanol }\end{array}$ & TAGs [27] \\
\hline $\begin{array}{l}\text { Review on microalgae } \\
\text { species }\end{array}$ & $\begin{array}{l}\text { Comparison of } 5 \text { different methods of extraction } \\
\text { (under pressure) } \\
\text { 2-ethoxyethanol was shown to provide superior } \\
\text { lipid recovery }\end{array}$ & $\begin{array}{l}\text { Linoleic acid } 18: 2 n-6 \\
\text { ARA } 20: 4 n-6 \\
\text { ALA } 18: 3 n-3, \\
\text { EPA, DHA [28] }\end{array}$ \\
\hline Tetraseimis sp. & $\begin{array}{l}\text { Classical lipid extraction using different solvents } \\
\text { and sonication, direct saponification and } \\
\text { supercritical } \mathrm{CO}_{2} \text { extraction, compared with } \\
\text { Soxhlet-based extraction. }\end{array}$ & Total lipids [29] \\
\hline $\begin{array}{l}47 \text { microalgae strains, } \\
\text { ind.green red algae, diatoms }\end{array}$ & $\begin{array}{l}\text { Direct extraction in n-hexane, sonication and } \\
\text { GC-MS analysis }\end{array}$ & Total lipids [12] \\
\hline
\end{tabular}

*Sweet water microalgae Abbreviations: Arahidonic acid - ARA; a-linolenic acid - ALA; Monounsaturated fatty acids- MUFAs; Poly unsaturated fatty acids - PUFAs; Monogalactosyl 
diacylglycerol - MGDG; Digalactosyl diacylglycerol - DGDG; Phosphatidylcholine-PC, Phosphatidylethanolamine - PE; Eicosapentanoic acid - EPA; Docosahexaenoic acid -DHA; Triacylglycerides -TAGs

The polyunsaturated fatty acids (PUFAs) play a key role in the microalgae biosynthesis, being key-molecules for the regulation of membrane fluidity, electron and oxygen transport, as well as thermal adaptation. Marine microalgae have been targeted as potential candidates for industrial production of $n-3$ LC-PUFAs such as eicosapentaenoic acid (EPA, 20:5n-3) and docosahexaenoic acid (DHA, 22:6n-3). EPA has been found in a wide variety of marine microalgal classes but only several species showed high production capacity (Table 3 ).

By the mevalonate pathway (Figure 1), many secondary metabolites are synthesized, mainly isoprenoids having specific roles in survival, adaptation to the environmental stress and defence against predators. Beside some terpenes and chlorophylls ( $a, b$ and $c)$, carotenoids, are the most important as main and accessory pigments for photosynthesis, as well sterols, as growing factors. The main carotenoids are $\beta$-carotene, lutein, astaxanthin and their esters (liposoluble) and apo-carotenoids or phycobilins (hydrosoluble). Such pigments exhibit colours from green, yellow, brown or red. Production of microalgal pigments may significantly vary dependent on many factors such as temperature, irradiation intensity, photoperiods, colour absorption wavelength, $\mathrm{pH}$, nutrient limitation, nitrogen supplements, salinity, presence of pesticides or heavy metals [30]. Table 4 presents the reference data related to the extraction, isolation and characterization of some isoprenoids, especially pigments

Table 4. Secondary metabolites (isoprenoids) identified and analysed from different species of microalgae. Relevant references are added.

\begin{tabular}{|c|c|c|}
\hline Microalgae species & Isoprenoids identified & References \\
\hline $\begin{array}{l}\text { Nannochloropsis } \\
\text { oculata/granulata } \\
\text { Nannochloropsis salina } \\
\text { Dunaliella sp. }\end{array}$ & $\begin{array}{l}\text { Violaxanthin/neoxanthin, astaxanthin, } \\
\text { vaucheriaxanthin, lutein/zeaxanthin, } \\
\text { canthaxanthin, fucoxanthin, } \beta \text {-cryptoxanthin, } \beta \text { - } \\
\text { carotene, } \alpha \text {-carotene, } \\
\text { Chlorophyll a, Fatty acids }\end{array}$ & {$[31],[32],[33]$} \\
\hline Chlamydomonas sp. & $\begin{array}{l}\text { phenolics, flavonoids, saponins, glycosides, } \\
\text { alkaloids, tannins, terpenoids, chlorophyll a, } \\
\text { chlorophyll b, astaxanthin }\end{array}$ & [33], [ 34] \\
\hline $\begin{array}{l}\text { Chlorella sp. * } \\
\text { Spirulina sp. }\end{array}$ & $\begin{array}{l}\text { phenolics, flavonoids, saponins, glycosides, } \\
\text { alkaloids, tannins, terpenoids, chlorophyll a, } \\
\text { chlorophyll b, astaxanthin, canthaxanthin, } \\
\text { zeaxanthin, violaxanthin, lutein }\end{array}$ & {$[2],[33],[34]$} \\
\hline
\end{tabular}

Among other secondary metabolites, it is important to mention also phytosterols, found in high quantities in some microalgae (Chlorella vulgaris, 
Tetraselmis suecica). The main sterols are ergosterol and fungisterol, useful as nutritional ingredients for aquaculture. Phytosterols are also effective as chemotaxonomic biomarker for distinguishing different algal species. Phytosterols extraction can be done by classical methods applied for lipids, using organic solvents or by green extraction technology through supercritical $\mathrm{CO}_{2}$ extraction [5], [34], [35].

Halogenated derivatives are found in several classes of primary and secondary metabolites, like indoles, terpenes, acetogenins, phenols, fatty acids and volatile halogenated hydrocarbons. They are present mainly in red and brown algae, such as cyanobacteria Anabaena cylindrica and Anabaena variabilis, found in river waters [19]. The extraction protocols for halogenated compounds may vary from classical extraction with conventional solvents (hexane, ethanol) to supercritical fluid extraction [31].

\section{EXTRACTION OF BIOACTIVE INGREDIENTS: CHALLENGES AND NEW TECHNIQUES}

The recovery of functional ingredients from microalgae is challenging and represents a critical step of extraction efficiency, mainly due to their thick and strong cell walls, the localization of products of interest into to cell membranes or in globules [36].

Cell disruption is a first challenge, considered a crucial step for the extraction of active ingredients from microalgae. Several methods, divided into two main groups, are currently available for cell disruption: mechanical (1) and (bio)chemical methods (2).

By mechanical stress (1) the cell wall is disrupted using solid-shear forces (e.g. bead mill, high speed homogenization), liquid-shear forces (high pressure homogenization, microfluidization), energy transfer through waves (e.g. ultrasonication, microwave), electric pulses or heat (e.g. thermolysis, autoclave procedures) [36]. Previous studies showed that high pressure homogenization it highly effective in disrupting the cell walls of different microalgae Chloroccum species, the rate disruption being maximal after five passes of homogenization [20]. High speed homogenization uses high rotation rates (around $8500 \mathrm{rpm} / \mathrm{min}$ ) to disrupt the cell wall by hydrodynamic cavitations, generated by the shear forces at the solid-liquid interphase, a simple, effective, but aggressive cell disruption method [36]. By ultrasonication, the microalgal biomass forms microbubble cavities which impart kinetic energy into the surface of the cells, causing ruptures of wall structure. As compared with high speed homogenization, the ultrasonication method was less effective 
on cell walls disruption, but more effective on disintegrating the microalgal colonies into single individual cells [20], [37], [38], when an acoustic power level of $65 \mathrm{~W}$ and $130 \mathrm{~W}$, was used for $25 \mathrm{~min}$. Microalgae cell disruption by ultrasonic treatment was evaluated also on Chlamydomonas reinhardtii [39] and it was shown that $800 \mathrm{~J} / 10 \mathrm{~mL}$ were needed to maximize the cell disruption, but is a risky procedure since free radicals can be released, affecting the quality of the sample.Bead milling is a mechanical blending unsing a physical grinding of the cell suspension with solid glass beads, the effeciency of disintegration increasing with bead loading [20]. A comparative study of different cell wall disrupting methods on Chlorella sp. showed that bead milling caused less wall breaking compared to grinding in liquid nitrogen [40]. Microwave treatment of cell suspensions at $2450 \mathrm{MHz}$ determines a local heating of intracellular polar molecules (maily water) which reach the boiling point, resulting in its expansion within the cell, increase of internal pressure and damage of the cell wall/membrane releasing intracellular metabolites [36]. Studies on Chlorella vulgaris and Scenedesmus sp. cells showed that microwave treatment was optimum [41].

The Pulsed electric field treatment induces critical electrical potentials and disrupts the cell wall by electromechanical compression and electric field-induced tension (electroporation). The electric field strength and pulses, the size and number of the pores may vary and can be reversible or irreversible, not only destroying the cell wall, but also the intracellular molecules [36]. Using such treatments on Auxenochlorella protothecoides, the extraction could be considerably improved, as reported recently [42]. The three-phase partitioning is a rapid, simple and scalable separation technique for concentration, isolation and decontamination of proteins from crude samples [7]. A recent study [11] showed that the aqueous extraction of proteins from several microalgae followed the order: high-pressure cell disruption > chemical treatment > ultrasonication > manual grinding. The cell-wall of microalgae mostly fragile followed the order: Haematococcus pluvialis < Nannochloropsis oculata < Chlorella vulgaris, $\leq$ Arthrospira platensis [43].

The (bio)chemical methods (2) consist in cells lysis with chemicals or enzymes and osmotic shock. These methods are milder than mechanical processes, the cells being only perforated or permeabilized rather than being break up [36]. The enzymatic degradation of cell walls can be produced by cellulase, lipase, chitinase enzymes, combined for an increased efficacy. In spite of its higher costs, this method has some important advantages such as the selectivity of degradation, protecting the unstable biochemicals, preserving their functionality. It was demonstrated that chitinase, lysozyme, pectinase, sulfatase, $\beta$-glucuronidase, and laminarinase had the broadest effect across 
the various Chlorella sp. strains and inhibited Nannochloropsis sp. and Nannochloris sp. strains [44], [45].

Cell disruption can be completed by several chemical compounds like antibiotics, chelating agents, chaotropes, detergents, solvents, hypochlorites, acids or alkali, but their selectivity is low, the efficiency being dependent on the cell wall composition [36].

New, emerging technologies are developing for microalgae cell disruption, e.g. explosive decompression with $\mathrm{CO}_{2}$, propane or butane, laser treatment, microfluidization, pulsed electric discharge, high frequency focused ultrasonication, etc. [36]. Unfortunately, none of the methods presented above are considered ideal. To chose the most appropriate method for cell wall disruption, should be taken into account the characteristics of each species, the active compound needed to be extracted, costs, applicability for industrial processes, etc.

Extraction procedures. Generally, the bioactive compounds can be extracted from natural resources by classical extraction techniques based on different polar and unipolar organic solvents, associated or not with heat, other supplementary techniques used to enhance the extraction yield. The existing classical techniques are Soxhlet extraction, maceration and hydrodistillation. Soxhlet extraction is generally used for nonpolar, lipid derivatives and uses volatile, non polar solvents by solid-lichid extraction process into a Soxhlet extractor. Maceration is a cheaper method to get essential oils and bioactive compounds, by grinding and mixing the solid material with a solvent, followed by filtration and centrifugation of the extract. The hydrodistillation process, uses water and steam distillation or direct steam distillation which involves a hydrodiffusion of bioactive polar components [46]. The selection of the proper solvent for extraction needs to consider the polarity of solvents and of compounds to be extracted, their molecular affinity, mass transfer, possible use of co-solvents, environmental safety, human toxicity and financial feasibility [46].

The modern extraction and isolation techniques on different natural sources, including microalgae have been described [20]. To mention, Supercritical-fluid Extraction (SFE), Pressurized-Liquid Extraction (PLE) and microwave-assisted (MAE), Ultrasound-Assisted Extraction (UAE) or SolidPhase Extraction (SPE) techniques, or their combination, were frequently used. In addition, the High-speed Counter-Current Chromatography (HCCC) provides also an effective liquid/liquid partition for metabolite isolation. Such techniques have been applied to the extraction of amino acids, fatty acids, natural pigments, saccharides, vitamins, toxins, and other metabolites from cyanobacteria, micro- or macro-algal species. The most commonly used SFE using $\mathrm{CO}_{2}$ due to its favourable critical temperature and pressure $\left(\mathrm{Tc}=31.1^{\circ} \mathrm{C}\right.$ 
and $\mathrm{Pc}_{\mathrm{c}}=73.9$ bar), is ideal for the extraction of thermolabile compounds. In addition, the supercritical $\mathrm{CO}_{2}$ has low viscosity, low surface tension, high diffusivity and good density and is also non-toxic, non-flammable, cheap, widely available, chemically inert under several conditions, and gaseous at normal pressure and temperature, eliminating the step of solvent evaporation after extraction. It gives a non-oxidizing atmosphere in extractions, thus preventing extracts from degradation [31]. A good example is the the use of this technique to extract carotenoids, clorophylls a, b and c from Scenedesmus obliquus, using different, optimal pressures and temperatures, depending on the active compound to be extracted [47]. MAE is an efficient method using microwave irradiation to accelerate the removal of a diversity of compounds from natural matrices, by concomitant heat and mass gradients [31]. Recent experimental results indicate that MAE increased extraction rate over 15 times for Chlorella sorokiniana and Nannochloropsis salina when compared with conventional solvent extraction [48]. UAE significantly reduces the extraction time and increases the extraction yields due to the production of cavitation bubbles in the solvent. This ability to cause cavitations depends on the characteristics of ultrasound wave, the solvent properties, and the ambient conditions [31]. Such methods were applied to extract lipids from Nannochloropsis oculata, at reduced extraction time and preservation of fatty acids quality [49]. PLE named also subcritical fluid extraction uses temperatures of $50-200^{\circ} \mathrm{C}$ and pressures in the range of 35-200 bar, lower than the Tc and $\mathrm{Pc}$ of the solvents, which are kept in the liquid state and therefore enhances the solubility and mass transfer rate, reduces the viscosity and surface tension of the solvents. Water is the most widely used solvent but also propane and dimethyl ether were repored [14]. Such technique was applied for a successful extraction of polysacharides with antiviral activity from Chlorella vulgaris [50].

\section{ANALYTICAL TECHNIQUES TO IDENTIFY AND QUANTIFY MICROALGAE METABOLITES}

UV-VIS Spectrometry. The quantitative determination of chlorophylls $a, b$ and carotenoids in a whole pigment extract of green microalgae by UVVIS spectroscopy is dependent by the sample characteristics, solvent system, and spectrophotometer parameters. For example, increasing the polarity of the solvent, the red absorption maximum of chlorophyll a shifts from 660 to 665 $\mathrm{nm}$, and the blue absorption maximum from 428 to $432 \mathrm{~nm}$. The same also applies to chlorophyll $b$, which shifts from 642 to $652 \mathrm{~nm}$ and 452 to $469 \mathrm{~nm}$. In order to perform spectroscopic measurements in the right maximum regions, 
one should determine the maximum red spectral position of pure chlorophyll a and $b$ solutions with one's own spectrophotometer and compare them with those from the literature. The absorption spectrum of an extract of a green tissue is generally containing mixtures of chlorophyll $a$ and $b$ and total carotenoids, being dominated by the absorption of chlorophyll $a$ at $A_{428}$ (blue) and $A_{661}(\mathrm{red})$. Chlorophyll $b$ and the carotenoids absorb broadly in the blue region $(400$ to $500 \mathrm{~nm})$ [51].

Traditionally, the quantification of microalgae carbohydrates is made by phenol-sulfuric acid protocol, where sugars are hydrolyzed to furans and measured spectrophotometrically at $490 \mathrm{~nm}$ for hexoses and $480 \mathrm{~nm}$ for pentoses and uronic acids [6]. For mycosporine-like aminoacids the quantification need absorbtion values at 330 and $310 \mathrm{~nm}$ [13].

Thin Layer Chromatography (TLC) and High Performance-Thin Layer Chromatography (HP-TLC). TLC is the oldest and widespread analytical chromatographic technique for the screening of plant and microalgae extracts. The separation process involves a suitable adsorbent (stationary phase) and a solvent or solvent mixture (mobile phase). By TLC methods, a broad range of substances dissolved in all solvents even aggressive reagents can be tested [52]. Recently, HP-TLS is often used also for screening the pigments from microalgae.

High-Performance Liquid Chromatography (HPLC) is the emerging technique to be used in laboratories worldwide over the past decades, coupled with UV- or photodiode array (PDA) detection. It is one of the best suited techniques for an efficient separation of the crude extracts or fractions. The reversed-phase columns are the best choice for the analytical separation, even if new stationary phases have been exploited [45]. Chromatography offers an efficient way to identify the carbohydrates, fatty acids, mycosporine like amino acids, carotenoids and other active compounds from microalgae [6], [20], [53]. Our present experimental studies are related to the application of HPLC-ESI ${ }^{+}-M S$ carotenoid profiles of Chlorella sorokiniana and other microalgae, either in aqueous suspensions or powders obtained by freeze drying [54].

Liquid Chromatography coupled with Mass Spectrometry (LC-MS) combines the high separation power of high-performance liquid chromatography with the structural information of mass spectrometry. The sensitivity and specificity of LC-MS methods are drastically improved relatively to the traditional UV/PDA detection and allows the use of very fast chromatographic separations with high peak purity value. A key 
development of this technique is the use of Electron Spray lonization (ESO) or Atmospheric Pressure Chemical Ionization (APCl) that transfers the analyte molecules from solution to the gas phase, suitable for fragmentation in the mass spectrometer [45]. LC-ESI/APCI-MS has been used to identify carotenoid esters present in extracts of pigmented freshwater microalgae and for the identification and quantification of glycolipids from microalgae [47].

Matrix Assisted Laser Desorption lonization time-of-flight mass spectrometry (MALDI-TOF-MS). MALDI-TOF MS is high performance technique ro screen the protein fingerprint and characterize the phenotype (genus, species), and in some cases, the strains also of microalgae, comparing the spectra of unknown microorganisms to reference spectra found in international databases [55].The possibility of using MALDI-TOFMS for the rapid identification of pathogenic and non-pathogenic species of the genus Prototheca has been recently demonstrated [30]. This provides reproductible and unique spectra covering a wide $\mathrm{m} / \mathrm{z}$ range (2000-20 000 $\mathrm{Da}$ ) for each of the strains used in the present study. The reproducibility of the spectra was further confirmed by employing composite correlation index calculation and main spectra library (MSP) dendrogram creation, available with MALDI Biotyper software [56].

\section{CONCLUSION}

Microalgae species have a high potential to synthesise a wide range and number of specific, bioactive metabolites, by a versatile metabolism, adaptative to environmental conditions. Considering the economic and health-beneficial action of their primary and secondary metabolites, new procedures and biorefinery technologies were released the last years. Bioactive molecules (amino acids and proteins, unsaturated lipids and fatty acids, sterols, carbohydrates, pigments, vitamins, etc.) may be extracted specifically by new, less distructive physical or biochemical procedures and then analysed by advanced techniques like high-performance chromatography coupled with mass spectrometry or by direct MALDI-TOF -MS screening. This overview may offer new ideas for improving the recovery and characterization of the microalgae biomass, as well considering the limits and challenges of such technologies. Nevertheless, supplementary scientific and technological inputs are expected in the next years for increasing the sustainability of microalgae biorefinery approach applied in this important category of natural resources. 
SCREENING OF BIOACTIVE COMPOUNDS SYNTHESIZED BY MICROALGAE ...

\section{ACKNOWLEDGMENTS}

This work was supported by a Research ERANET-LAC project SCREAM nr.26/2016, funded by the Romanian National Authority for Scientific Research and Innovation UEFISCDI, within PNCDI III program.

\section{REFERENCES}

1. E. Christaki, E. Bonos, I. Giannenas, P. C. Florou-Paneri, Journal of the Science of Food and Agriculture, 2013, 93(1), 5.

2. M. Greque de Morais, B. da Silva Vaz, E. Greque de Morais, J.A. Vieira Costa, BioMed Research International, 2015, ID 835761, 1.

3. A. Villarruel-Lopez, F. Ascencio, K.Nuno, Polish Journal Of Food And Nutrition Sciences , 2017, 67, 251

4. K.H. Wiltshire, M. Boersma, A. Möller, H. Buhtz, Aquatic Ecology, 2000, 34, 120.

5. S.M. Mostafa, Plant Science, 2012, chapter 12.

6. K.H.M. Cardozo, T. Guaratini, M.P. Barros, V.R. Falcão, A.P. Tonon, N.P. Lopes, S. Campos, M.A. Torres, A.O. Souza, P. Colepicolo, E. Pinto, Comparative Biochemistry and Physiology, 2007, C 146, 60.

7. E. Gunerken, E. D'Hondt, M.H.M. Eppink, L. Garcia-Gonzalez, K. Elst, R.H. Wijfels, Biotechnology Advances, 2015, 33(2), 243.

8. A.G. Waghmare, M.K. Salve, J.G. LeBlanc, S.S. Arya, Bioresources and Bioprocessing, 2016, 3, 16.

9. D.W. Templeton, M. Quinn, S. Van Wychen, D. Hyman, L.M.L. Laurens, Journal of Chromatography A, 2012, 1270, 225.

10. Z. Cheng-Wu, O. Zmora, R. Kopel, A. Richmond, Aquaculture, 2001, 195, 35.

11. Z. Cohen, M. Reungjitchachawali, W. Siangdung, M. Tanticharoen, Journal of Applied Phycology, 1993, 24, 312.

12. C. Safi, A.V. Ursu, C. Laroche, B. Zebib, O. Merah, P.Y. Pontalier, C. VacaGarcia, Algal Research, 2014, 3, 61.

13. A.Z. Mustopa, R. Isworo, M. Nurilmala, D. Susilaningsih, Annales Bogorienses, 2016, 20(2), 47.

14. C. Schulze, M. Wetzel, J. Reinhardt, M. Schmidt, L. Felten, S. Mundt, Journal of Applied Phycology, 2016, 28, 2719.

15. C.A. Llewellyn, R.L. Airs, Marine Drugs, 2010, 8, 1273.

16. J.I. Carreto, M.O. Carignan, N.G Montoya, Marine Biology, 2005, 146, 237.

17. Y. Li, F. Ghasemi Naghdi, S. Garg, T.C. Adarme-Vega, K.J. Thurecht, W.A. Ghafor, S. Tannock, P.M. Schenk, Microbial Cell Factories, 2014, 13(1), 1.

18. S.S. Suh, J. Hwang, M. Park, H.H. Seo, H.S. Kim, J.H Lee, S.H. Moh, T.K. Lee, Marine Drugs, 2014, 12(10), 5174. 
19. M. Henriques, A. Silva, J. Rocha, Extraction and quantification of pigments from a marine microalga: a simple and reproducible method, Communicating Current Research and Educational Topics and Trends in Applied Microbiology, Formatex, Spain, Vol. 2, 2007, 586.

20. A. Ilavarasi, D. Pandiaraj, D. Mubarakali, M.H. Ilyas, N. Thajuddin, Pakistan Journal of Biological Sciences, 2012, 15, 883.

21. S.M. Abdo, E. Ahmed, S. Abo El-Enin, R.S. El Din, G. El Diwani, G. Ali, Journal of Algal Biomass Utilization, 2014, 5(3), 23.

22. C. Hu, M. Li, J. Li, Q. Zhu, Z. Liu, World Journal of Microbiology and Biotehnology, 2008, 24, 1209.

23. Y. Jiang, K.W. Fan, R.T.Y. Wong, F. Chen, Journal of Agricultural and Food Chemistry, 2004, 52(5),1196.

24. J. Maligan, A. Saksony, V. Widayanti, Conference Proceeding, 2011.

25. A.P. Carvalho, F.X. Malcata, Marine Biotechnology, 2005, 7(4), 381.

26. N. Sato, M. Tsuzuki, A. Kawaguchi, Biochimica et Biophysica Acta, 2003, 1633(1), 35.

27. E. Ryckebosch, K. Muylaert, I. Foubert, Journal of the American Oil Chemists' Society, 2012, 89, 189.

28. E.C. Carballo-Cárdenas, P.M. Tuan, M. Janssen, R.H. Wijfels, Biomolecular Engineering, 2003, 20(4-6), 139.

29. T. Rezanka, L. Nedbalová, L. Procházková, K. Sigler, Phytochemistry, 2014, 100, 34.

30. E. da Costa, J. Silva, S. Hoffman Mendonça, M.H. Abreu, M.R. Domingues, Marine Drugs, 2016, 14(101), 1.

31. S. Ramaraj, J.S. Ki, A Review of the Biological Activities of Microalgal Carotenoids and Their Potential Use in Healthcare and Cosmetic Industries, Marine Drugs, 2018, 16, article 26.

32. C. Grosso, P. Valentão, F. Ferreres, P. Andrade, Marine Drugs, 2015, 13, 3184.

33. B. Tartarotti, R. Sommaruga, Archiv für Hydrobiologie, 2002, 154(4), 691.

34. K. Skjånes, C. Rebours, P. Lindblad, Critical Reviews in Biotechnology, 2013, 33(2), 195.

35. A. Jayshree, N. Thangaraju, Journal of Algal Biomass Utilization, 2014, 5, 61

36. D. Mouna, H. Bilel, M.Barkallah, et al., Bioresource Technology , 2018, 249, 510

37. E. Gunerken, E. D'Hondt, M.H.M. Eppink, L. Garcia-Gonzalez, K. Elst, R.H. Wijfels, Biotechnology Advances, 2015, 33(2), 243.

38. C.W. Yong, L. H. Yong, Applied Sciences-Basel, 2018, 8, article 26

39. M.Stramarkou, S.Papadaki, K. Kyriakopoulou et al, J. Applied Phycology, 2017, 29, 2947.

40. J.A. Gerde, M. Montalbo-Lomboy, L. Yao, D. Grewell, T. Wang, Bioresource Technology, 2012, 125, 175.

41. H. Zheng, J. Yin, Z. Gao, H. Huang, X. Ji, C. Dou, Applied Biochemistry and Biotechnology, 2011, 164, 1215.

42. J.Y. Lee, C. Yoo, S.Y. Jun, C.Y. Ahn, H.M. Oh, Bioresource Technology, 2010, 101(1), S75. 
43. C. Eing, M. Goettel, R. Straessner, C. Gusbeth, W. Frey, IEEE Transactions on Plasma Science, 2013, 41(10), 2901.

44. S. Papadaki, K. Kyriakopoulou, K. Magdalini, IOSR Journal of Environmental Science, Toxicology and Food Technology, 2017, 10, 53.

45. H.G. Gerken, B. Donohoe, E.P. Knoshaug, Planta, 2013, 237(1), 239.

46. J. Asma, R. Brandon, H. Soleiman et al., Biomedical Journal, et al. 2017, 40, 339.

47. J. Azmir, I.S.M. Zaidul, M.M. Rahman, K.M. Sharif, A. Mohamed, F. Sahena, M.H.A. Jahurul, K. Ghafoor, N.A.N. Norulaini, A.K.M. Omar, Journal of Food Engineering, 2013, 117(4), 426.

48. A.C. Guedes, M.S. Giao, A.A. Matias, A.V.M. Nunes, M.E. Pintado, C.M.M. Duarte, F.X. Malcata, Journal of Food Engineering, 2013, 116, 478.

49. J. Pan, T. Muppaneni, Y. Sun, H.K. Reddy, J. Fu, X. Lu, S. Deng, Fuel, 2016, $178,49$.

50. F. Adam, M. Abert-Vian, G. Peltier, F. Chemat, Bioresource Technology, 2012, 114(5), 457.

51. S. Santoyo, M. Plaza, L. Jaime, E. Ibanez, G. Reglero, F.J. Senorans, Journal of Agricultural and Food Chemistry, 2010, 58, 8522.

52. D. Martin-Creuzburg, P. Merkel, Journal Plankton Research, 2016, 38(4), 865.

53. H.K. Lichtenthaler, C. Buschmann, Chlorophylls and carotenoids: measurement and characterization by UV-VIS spectroscopy, Current Protocols in Food Analytical Chemistry, John Wiley \& Sons, Inc., 2001, UNIT F4.3.

54. A.Bertoli, B. Ruffoni, L. Pistelli, L. Pistelli, Analytical methods for the extraction and identification of secondary metabolite production in 'In Vitro' Plant Cell Cultures, Bio-Farms for Nutraceuticals, Springer US, 2010, Chapter 19.

55. C. Moraru, K. Skjanes, D. Patras, C. Socaciu, CJJ Spetz, Proc. $18^{\text {th }}$ Int. Symp. On Carotenoids, Basel, 9-14 July 2017 (poster presentation).

56. I. Lang, L. Hodac, T. Friedl, I. Feussner, BMC Plant Biology, 2011, 11, 124.

57. D. Barbano, R. Diaz, L. Zhang, T. Sandrin, H. Gerken, T. Dempster, PLOS One, 2015, 10(8). 